\title{
PERLINDUNGAN TERHADAP KELOMPOK MINORITAS DI INDONESIA DALAM MEWUJUDKAN KEADILAN DAN PERSAMAAN DI HADAPAN HUKUM
}

\author{
(Minority Group Protection in Indonesia to Realize Justice and Equality Before the Law)
}

\author{
Danang Risdiarto \\ Badan Pembinaan Hukum Nasional \\ Jl. Mayjen Sutoyo No.10, Cililitan, Jakarta Timur 13640 \\ Email: risdiarto@bphn.go.id
}

Naskah diterima: 23 Maret 2017; revisi: 11 April 2017 disetujui: 17 April 2017

\begin{abstract}
Abstrak
Era reformasi memiliki cita-cita untuk menciptakan demokrasi di seluruh aspek kehidupan, tegaknya kedaulatan hukum dan penghormatan terhadap hak-hak asasi manusia tanpa diskriminasi, namun ironisnya kebebasan di era reformasi justru memunculkan tindak kekerasan dan diskriminasi terhadap kelompok minoritas. Sebagian warga negara Indonesia yang tergolong dalam kelompok minoritas ternyata belum mendapat perhatian yang serius dari pemerintah. Oleh sebab itu perlu diteliti perlindungan hukum apa saja yang telah diberikan oleh Negara terhadap kelompok minoritas di Indonesia. Penelitian ini dilakukan dengan metode yuridis normatif yang dilakukan melalui studi pustaka yang menelaah data sekunder yaitu peraturan perundang-undangan, hasil penelitian, hasil pengkajian dan referensi lainnya yang terkait pengaturan terhadap kelompok minoritas dalam mewujudkan hak asasinya untuk memperoleh keadilan dan persamaan di hadapan hukum. Dari hasil penelitian dapat diketahui bahwa pemerintah saat ini sudah melakukan berbagai upaya untuk melakukan perlindungan hukum terhadap kelompok minoritas. Hal tersebut bisa dilihat dari berbagai regulasi dan kebijakan yang diterbitkan. Perlindungan hukum terhadap hak asasi kelompok minoritas di Indonesia diatur dalam Pasal 28 D dan Pasal 28 I Undang-Undang Dasar 1945, serta tercantum juga di Pasal 3 ayat (3) Undang-Undang Nomor 39 Tahun 1999 tentang HAM. Sedangkan Pasal 27 Kovenan Internasional Hak-Hak Sipil dan Politik (International Covenant and Political Rights) yang telah diratifikasi dengan Undang-Undang Nomor 12 Tahun 2005 mengatur bahwa kelompok minoritas tersebut harus diakui berbagai haknya. Salah satu permasalahan dalam penyelenggaraan hak-hak minoritas di Indonesia adalah lemahnya penegakan hukum dan pembangunan yang berkeadilan serta perlakuan diskriminatif lainnya yang masih sering terjadi kepada mereka. Sudah sepatutnya pemerintah mengedepankan pendekatan berbasis HAM (rights based approach) dalam seluruh proses pembangunan program dan kebijakan yang disusun sesuai dengan upaya perlindungan serta pemenuhan hak-hak kelompok minoritas.
\end{abstract}

Kata Kunci: kelompok minoritas, keadilan, persamaan di hadapan hukum, hak asasi manusia

\begin{abstract}
The reform era has aspiration to create democracy in all aspects of life, upholding the rule of law and respect for human rights without discrimination. But, ironically freedom in the reform era actually brings violence and discrimination against minorities. Most of Indonesian citizens who belong to the minority group had not yet received serious attention from the government. Therefore, it is necessary to study any legal protection that has been given by the State to the minority group in Indonesia. This research has been conducted by using normative legal research methods by reviewing literatures that examines secondary data, namely regulations, results of research, reviews and other references related to the regulations on minority group in obtaining justice and equality before the law. The study shows that the government has made efforts to provide legal protection against minorities. That can be seen from various regulations and policies issued. Legal protection of the rights of minority group in Indonesia is regulated in Article 28 and Article 28 I Constitution of Indonesia of 1945, and also contained in Article 3 Paragraph (3) of Law Number 39 Year 1999 about Human Rights. While, Article 27 of the International Covenant on Civil and Political Rights, which has been ratified by Law Number 12 of 2005 on Ratification of the ICCPR 1966 regulates that such the rights of minorities shall be recognized. One of the problems in the implementation of minority rights in Indonesia is the weakness of law enforcement and equitable development as well as other discriminatory treatment that still common happens to them. The government should promote human rights based approach (rights-based approach) in the whole process of development programs and policies that prepared in accordance with the protection and fulfillment of the rights of minority group.
\end{abstract}

Keywords: minority group, justice, equality before the law, human rights 


\section{A. Pendahuluan}

Sesudah jatuhnya rezim Orde Baru, yang selama 32 tahun hampir dihiasi dengan beragamnya pelanggaran Hak Asasi Manusia (HAM), era reformasi memiliki cita-cita untuk menciptakan demokrasi di seluruh aspek kehidupan, tegaknya kedaulatan hukum dan penghormatan terhadap hak-hak asasi manusia tanpa diskriminasi. Namun kebebasan di era reformasi justru memunculkan tindak kekerasan dan diskriminasi terhadap kelompok minoritas yang tak kalah serampangan dengan penguasa otoriter rezim lama.

Berbagai tindakan diskriminasi terhadap kelompok minoritas telah melahirkan pelanggaran HAM serta kejahatan terhadap kemanusiaan. Dalam konteks hak kebebasan beragama, tindakan kekerasan dan diskriminasi dialami jemaat GKI Yasmin dan HKBP Filadelfia untuk mendirikan rumah ibadah. Baru-baru ini pula terjadi kekerasan serupa yang menimpa Gereja Santa Clara di Bekasi. Massa gabungan berbagai organisasi masyarakat (ormas) menolak pendirian gereja tersebut meskipun telah mendapatkan Izin Mendirikan Bangunan (IMB) sejak 28 Juli 2015. Pendirian Gereja Santa Clara juga sudah mendapat rekomendasi dari Forum Kerukunan Umat Beragama Kota Bekasi yang mengklaim telah menjalankan Peraturan Bersama Menteri Agama dan Menteri Dalam Negeri Nomor 8 dan 9 Tahun 2006 tentang Pendirian Rumah Ibadah. ${ }^{1}$ Sebagian warga negara Indonesia yang tergolong dalam kelompok minoritas ternyata belum mendapat perhatian yang serius dari pemerintah. Itu terlihat dari laporan awal Pelapor Khusus ${ }^{2}$ Kelompok Minoritas yang dibentuk Komnas HAM. Ketua Komnas HAM mengatakan dari berbagai isu HAM yang diperjuangkan Komnas HAM, salah satu isu yang paling berat menyangkut soal kelompok minoritas. Isu kelompok minoritas seringkali memicu kontroversi berbagai pihak sehingga menghambat upaya penegakan HAM. Masyarakat Indonesia secara umum masih awam dalam melihat kelompok minoritas. Sesuatu yang berbeda dengan mainstream atau kebiasaan umum seringkali dianggap asing, abnormal atau kesalahan. Pemahaman itu harus dibenahi karena konstitusi mengamanatkan semua manusia memiliki derajat yang sama sehingga tidak boleh ada diskriminasi atas

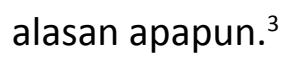

Ditegaskan juga dalam Undang-Undang Nomor 39 Tahun 1999 tentang Hak Asasi Manusia bahwa kelompok minoritas harus mendapat perlakuan dan perlindungan yang sama di depan hukum. Lebih khusus Kovenan Hak-Hak Sipil dan Politik yang telah diratifikasi lewat Undang-Undang Nomor 12 Tahun 2005 tentang Pengesahan International Covenant On Civil And Political Rights (Kovenan Internasional Tentang Hak-Hak Sipil Dan Politik), menegaskan kepada negara pihak untuk menghormati hakhak kelompok minoritas meliputi etnis, bahasa atau agama. Melihat keberagaman di Indonesia, Komnas HAM memasukkan beberapa kelompok

http://www.cnnindonesia.com/nasional/20170324163936-20-202562/wali-kota-bekasi-effendi-disalahkansoal-gereja-santa-clara/ (diakses 31 Maret 2017).

2 Pelapor Khusus adalah para Anggota Komnas HAM yang mempunyai keahlian dan minat di bidang tema tertentu dan oleh karena itu mereka mempunyai kewenangan melakukan pendalaman dan pengamatan terhadap tema tersebut.

3 http://www.hukumonline.com/berita/baca/lt574e8e59757a1/ini-catatan-komnas-ham-terhadappemenuhan-hak-kelompok-minoritas (diakses 31 Maret 2017). 
dalam golongan minoritas seperti penyandang disabilitas, Lesbian, Gay, Biseksual, dan Transgender (LGBT), dan aliran politik minoritas. Komnas HAM mendorong pemerintah untuk memajukan pemenuhan hak-hak kelompok minoritas. Dengan begitu diharapkan ada perlindungan terhadap kelompok minoritas yang menjalankan keyakinannya dan mengekspresikan identitas mereka masingmasing

Dalam perspektif HAM, kelompok minoritas berada pada tingkat setara dengan individuindividu pemangku hak yang lain. Namun, karena senyatanya kelompok minoritas adalah warga kelas yang tersubordinasi, maka dibutuhkan hak khusus untuk mengangkat martabat mereka. Hak khusus bukanlah hak istimewa, tapi hak ini diberikan agar kaum minoritas mampu menjaga identitas, ciri-ciri dan tradisi khasnya. Hak khusus seperti ini penting untuk mencapai perlakuan yang sama tanpa diskriminasi. Berdasarkan latar belakang diatas maka penelitian ini akan mengangkat permasalahan utama yaitu: perlindungan hukum apa saja yang telah diberikan oleh Negara terhadap kelompok minoritas di Indonesia dalam mewujudkan keadilan dan persamaan di hadapan hukum.

\section{B. Metode Penelitian}

Penelitian ini dilakukan dengan metode yuridis normatif yang dilakukan melalui studi pustaka yang menelaah (terutama) data sekunder yaitu peraturan perundangundangan, hasil penelitian, jurnal ilmah, hasil pengkajian dan referensi lainnya ${ }^{4}$. Metode ini juga digunakan untuk mengungkapkan berbagai perangkat hukum yang terkait pengaturan terhadap perlindungan hukum terhadap kelompok minoritas Indonesia.

Pengumpulan data dilakukan dengan meneliti data mengenai peraturan perundangundangan yang mengatur tentang keadilan dan persamaan di hadapan hukum bagi kelompok minoritas di Indonesia dan peraturan lain dibawahnya yang berkaitan dengan hal tersebut.

Sedangkan untuk teknik pengumpulan data bagi kegiatan ini dilakukan melalui penelitian kepustakaan ${ }^{5}$. Penelitian ini dimaksudkan untuk mencari landasan teoritis (filosofis, yuridis, ekonomi) juga berbagai informasi mengenai pelaksanaan perlindungan kelompok minoritas Indonesia. Bahan hukum sekunder yang digunakan yaitu buku-buku, karya ilmiah dan hasil penelitian yang berkaitan dengan objek yang dibahas. Pengumpulan data dilengkapi pula dengan artikel hukum dari internet ataupun artikel ilmiah lainnya yang dapat mendukung kelengkapan data dalam penelitian ini. Data dari hasil penelitian ini kemudian dianalisa secara kualitatif, artinya data kepustakaan dianalisa secara mendalam, holistik, dan komprehensif. Penggunaan metode analisa kualitatif didasarkan pada pertimbangan data yang dianalisa beragam, memiliki perbedaan antara satu dengan lainnya, serta tidak mudah untuk dikuantitatifkan.

\section{Pembahasan}

\section{Tipologi Kelompok Minoritas di Indonesia}

Hingga saat ini belum ada kesepakatan internasional terkait minoritas yang bersifat

Lampiran I Undang-Undang Nomor 12 Tahun 2011 tentang Pembentukan Peraturan Perundang-Undangan.

Soerjono Soekanto dan Sri Mamudji, Penelitian Hukum Normatif. Suatu Tinjauan Singkat, (Jakarta: Raja Grafindo Persada, 2004), hlm. 29-33. 
mengikat. Di Indonesia, berbagai keragaman pengertian terkait minoritas juga terjadi. Dalam Kamus Besar Bahasa Indonesia disebutkan pengertian minoritas adalah golongan sosial yang jumlah warganya jauh lebih kecil jika dibandingkan dengan golongan lain dalam suatu masyarakat dan karena itu didiskriminasikan oleh golongan lain itu. ${ }^{6}$

Sedangkan Komnas HAM memberikan definisi minoritas dengan kata-kata kunci yang harus dipertimbangkan yaitu: "secara leksikal, istilah "minoritas" dapat dipahami secara numerik yaitu sebagai populasi yang jumlahnya lebih sedikit dari sebuah jumlah populasi yang lebih besar secara keseluruhan (di tingkat nasional). Tapi minoritas juga dapat dilihat dalam hal pengaruh, yaitu tidak dominan, dan mendapat perlakuan yang merugikan atau berada dalam situasi yang tidak diuntungkan dalam kehidupan bermasyarakat dan bernegara." 7

Selain itu Komnas HAM juga menawarkan ruang lingkup kelompok minoritas untuk konteks Indonesia adalah:

1) Kelompok Minoritas Ras

Secara kategorial, kelompok-kelompok minoritas rasial yang mendapat perhatian khusus dari Komnas HAM meliputi tiga kelompok yaitu Tionghoa, etnis-agama seperti kelompok Sikh, Yahudi, Tao, dan lainnya, serta kelompok yang dalam UU Otonomi Khusus Papua disebut sebagai orang-orang asli Papua ${ }^{8}$
2) Kelompok Minoritas Etnis

Definisi etnis dipahami sebagai penggolongan manusia berdasarkan kepercayaan, nilai, kebiasaan, adat istiadat, norma bahasa, sejarah, geografis, dan hubungan kekerabatan. Jika dihubungkan dengan penggolongan etnis, aspek bahasa sebenarnya menjadi elemen penting yang membedakan satu etnis dengan etnis lain. Maka keragaman etnis yang didasarkan dari perbedaan-perbedaan bahasa merupakan fakta tingginya tingkat keragaman di tengah masyarakat Indonesia. ${ }^{9}$

3) Kelompok Minoritas Agama dan Keyakinan Negara melakukan pengutamaan pada enam agama yang disebut dalam penjelasan Pasal 1 Undang-Undang Nomor 1/PNPS/1965, yang memberikan jaminan kebebasan dan fasilitas serta bantuan-bantuan dan perlindungan. TAP MPR Nomor IV/ MPR/1978 tentang Garis-Garis Besar Haluan Negara (GBHN) telah menegaskan bahwa "aliran kepercayaan terhadap Tuhan yang Maha Esa tidak merupakan agama". Hal ini jelas merupakan tindakan diskriminatif terhadap kelompok-kelompok masyarakat yang kepercayaannya tidak dimasukkan sebagai "agama". ${ }^{10}$

4) Kelompok Penyandang Disabilitas Siapa yang disebut sebagai "Penyandang Disabilitas" dalam hal ini termasuk mereka yang memiliki keterbatasan fisik, mental, intelektual, atau sensorik dalam jangka waktu lama, ketika berhadapan dengan 
berbagai hambatan, keterbatasan tersebut dapat menghalangi partisipasi mereka secara penuh dan efektif dalam masyarakat berdasarkan kesetaraan. ${ }^{11}$

5) Kelompok Minoritas Berdasarkan Identitas Jender dan Orientasi Seksual

Fokus pembahasan kelompok minoritas ini ditujukan bagi kelompok LGBTI (Lesbian, Gay, Biseksual, Transjender dan Interseksual) yang sehari-hari mengalami bukan hanya tindakan diskriminatif, namun juga berbagai kekerasan karena dianggap "menyimpang". ${ }^{12}$

\section{Prinsip Keadilan di Negara Hukum}

Hukum mempunyai posisi strategis dan dominan dalam kehidupan masyarakat berbangsa dan bernegara. Hukum sebagai suatu sistem, dapat berperan dengan baik dan benar ditengah masyarakat jika instrumen pelaksanaannya dilengkapidengan kewenangankewenangan dalam bidang penegakan hukum.

Kepastian hukum oleh setiap orang dapat terwujud dengan ditetapkannya hukum dalam hal terjadi peristiwa konkret. Hukum yang berlaku pada dasarnya tidak dibolehkan menyimpang, hal ini dikenal juga dengan istilah fiat justitia et pereat mundus (meskipun dunia ini runtuh hukum harus ditegakkan). Itulah yang diinginkan oleh kepastian hukum. Kepastian hukum merupakan perlindungan terhadap tindakan sewenang-wenang, yang berarti bahwa seseorang akan dapat memperoleh sesuatu yang diharapkan dalam keadaan tertentu. Masyarakat mengharapkan adanya kepastian hukum, karena dengan adanya kepastian hukum masyarakat akan lebih tertib. Hukum bertugas menciptakan kepastian hukum karena bertujuan ketertiban masyarakat. Sebaliknya masyarakat mengharapkan manfaat dalam pelaksanaan atau penegakan hukum.

Hukum adalah untuk manusia, maka pelaksanaan hukum atau penegakan hukum harus memberi manfaat atau kegunaan bagi masyarakat. Hukum tidak identik dengan keadilan. Hukum itu bersifat umum, mengikat setiap orang, bersifat menyamaratakan. Barangsiapa mencuri harus dihukum, dimana setiap orang yang mencuri harus dihukum, tanpa membeda-bedakan siapa yang mencuri. Kepastian hukum sangat identik dengan pemahaman positivisme hukum. Positivisme hukum berpendapat bahwa satu-satunya sumber hukum adalah undang-undang, sedangkan peradilan berarti semata-mata penerapan undang-undang pada peristiwa yang konkret. Penegakan hukum yang mengutamakan kepastian hukum juga akan membawa masalah apabila penegakan hukum terhadap permasalahan yang ada dalam masyarakat tidak dapat diselesaikan berdasarkan hati nurani dan keadilan. Rasa keadilan adalah harapan yang harus dipenuhi dalam penegakan hukum.

Berdasarkan karakteristiknya, keadilan bersifat subyektif, individualistis dan tidak menyamaratakan. Apabila penegak hukum menitikberatkan kepada nilai keadilan sedangkan nilai kemanfaatan dan kepastian hukum dikesampingkan, maka hukum itu tidak dapat berjalan dengan baik. Demikian pula sebaliknya jika menitikberatkan kepada nilai kemanfaatan sedangkan kepastian hukum dan keadilan dikesampingkan, maka hukum itu tidak jalan. Idealnya dalam menegakkan hukum itu nilai-nilai dasar keadilan yang merupakan nilai

$11 \quad$ Ibid, hlm. 76.

12 Ibid, hlm. 95. 
dasar filsafat dan nilai-nilai dasar kemanfaatan merupakan suatu kesatuan berlaku secara sosiologis, serta nilai dasar kepastian hukum yang merupakan kesatuan yang secara yuridis harus diterapkan secara seimbang dalam penegakan hukum.

Hal menarik yang perlu dicermati apabila terdapat 2 (dua) unsur yang saling tarikmenarik antara keadilan dan kepastian hukum, Roeslan Saleh mengemukakan: "keadilan dan kepastian hukum merupakan dua tujuan hukum yang kerap kali tidak sejalan satu sama lain dan sulit dihindarkan dalam praktik hukum. Suatu peraturan hukum yang lebih banyak memenuhi tuntutan kepastian hukum, maka semakin besar pada kemungkinannya aspek keadilan yang terdesak. Ketidaksempurnaan peraturan hukum ini dalam praktik dapat diatasi dengan jalan memberi penafsiran atas peraturan hukum tersebut dalam penerapannya pada kejadian konkret. Apabila dalam penerapannya dalam kejadian konkret, keadilan dan kepastian hukum saling mendesak, maka hakim sejauh mungkin harus mengutamakan keadilan di atas kepastian hukum". ${ }^{13}$

Roscoe Pound sebagai salah satu ahli hukum terkenal dengan teorinya yang menyatakan bahwa, "hukum adalah alat untuk memperbarui (merekayasa) masyarakat (law as a tool of social engineering)". Banyak perubahan penting dalam masyarakat yang sudah maju diawali dari suatu perubahan hukum, khususnya perubahan undang-undang. Meskipun harus diakui pula perubahan hukum tersebut biasanya dipacu oleh adanya perubahan dalam masyarakat lokal maupun masyarakat internasional. Tetapi perubahan dalam masyarakat tersebut belum sah berlakunya sebelum dilegalkan oleh undang-undang, khususnya bagi perkembangan perbuatan, peristiwa, mode, yang ada relasi erat dengan masyarakat luas dan negara. Setiap ada perancangan atas undang-undang, berarti sedang dilakukan perancangan atas suatu perubahan dalam masyarakat. ${ }^{14}$

Fungsi hukum sangat luas termasuk untuk rekonsiliasi, harmonisasi dan kompromi atas seluruh konflik kepentingan dalam masyarakat (individu, publik dan negara), dengan prinsip hanya untuk kepentingan yang terbanyak dengan pengorbanan sekecil-kecilnya kepentingan orang lain. Itulah yang disebut hukum sebagai sarana 'social engineering' ${ }^{15}$

Pernyataan Pound ini ditafsirkan Mochtar Kusumaatmadja dalam konteks pembangunan hukum nasional di Indonesia yang intinya bagaimana memerankan hukum sebagai sarana pembaruan masyarakat ${ }^{16}$. Salah satu pembaruan yang amat penting di masyarakat adalah mewujudkan suatu rasa keadilan bagi kaum minoritas di Indonesia.

Dengan demikian, bahwa kedudukan keadilan merupakan unsur yang sangat penting dalam penegakan hukum di Indonesia. Indonesia memiliki kultur masyarakat yang beragam dan memiliki nilai yang luhur, tentunya sangat

Roeslan Saleh dikutip dalam Bismar Siregar, Kata Hatiku, Tentangmu (Jakarta: Diandra Press, 2008), hlm. 121122.

14 Munir Fuady, Teori-Teori Besar (Grand Theory) Dalam Hukum, (Jakarta: Kencana, 2013), hlm. 248-260.

15 Satjipto Rahardjo, Hukum dan Perubahan Sosial. Suatu Tinjauan Teoretis serta Pengalaman-Pengalaman di Indonesia, (Bandung: Alumni, 1983), hlm. 146-163.

16 Romli Atmasasmita, Teori Hukum Integratif. Rekonstruksi Terhadap Teori Hukum Pembangunan dan Teori Hukum Progresif, (Yogyakarta: Genta Publishing, 2012), hlm. 41-42. 
mengharapkan keadilan dan kemanfaatan yang dikedepankan dibandingkan unsur kepastian hukum. Keadilan merupakan hakekat dari hukum, sehingga penegakan hukum pun harus mewujudkan hal demikian. Di samping kepastian hukum dan keadilan, unsur lain yang perlu diperhatikan adalah kemanfaatan. Masalah kepastian hukum bukan urusan undang-undang semata, melainkan lebih merupakan urusan perilaku manusia. Kepastian hukum itu menjadi masalah besar sejak hukum itu dituliskan. Sebelum itu, selama ribuan tahun, apabila kita berbicara mengenai hukum, maka kita lebih banyak berbicara mengenai keadilan.

\section{Konsep Persamaan di Hadapan Hukum di Indonesia}

Equality before the law dalam arti sederhananya bahwa semua orang sama di depan hukum. Persamaan dihadapan hukum atau equality before the law adalah salah satu asas terpenting dalam hukum modern. Asas ini menjadi salah satu sendi doktrin Rule of Law yang juga menyebar pada negara-negara berkembang seperti Indonesia. Perundangundangan Indonesia mengadopsi asas ini sejak masa kolonial lewat Burgelijke Wetboek (KUHPerdata) dan Wetboek van Koophandel voor Indonesie (KUHDagang) pada 30 April 1847 melalui Stb. 1847 Nomor 23. Tapi pada masa kolonial itu, asas ini tidak sepenuhnya diterapkan karena politik pluralisme hukum yang memberi ruang berbeda bagi hukum Islam dan hukum adat di samping hukum kolonial.

Sejatinya, asas persamaan di hadapan hukum bergerak dalam payung hukum yang berlaku umum (general) dan tunggal. Ketunggalan hukum itu menjadi satu wajah utuh diantara dimensi sosial lain (misalkan terhadap ekonomi dan sosial). Persamaan "hanya" dihadapan hukum seakan memberikan sinyal di dalamnya bahwa secara sosial dan ekonomi orang boleh tidak mendapatkan persamaan. Perbedaan perlakuan "persamaan" antara di dalam wilayah hukum, wilayah sosial dan wilayah ekonomi itulah yang menjadikan asas persamaan dihadapan hukum tergerus ditengah dinamika sosial dan ekonomi.

Undang-Undang Dasar 1945 secara tegas telah memberikan jaminan bahwa "segala warga negara bersamaan kedudukannya di dalam hukum dan pemerintahan dan wajib menjunjung hukum dan pemerintahan itu dengan tidak ada kecualinya" dalam Pasal 27 ayat (1). Pasal ini memberikan makna bahwa setiap warga negara tanpa harus melihat apakah dia penduduk asli atau bukan, berasal dari golongan terdidik atau rakyat jelata yang buta huruf, golongan menengah ke atas atau kaum yang bergumul dengan kemiskinan harus dilayani sama di depan hukum.

Kedudukan berarti menempatkan warga negara mendapatkan perlakuan yang sama di hadapan hukum. Sehingga dengan kedudukan yang setara, maka warga negara dalam berhadapan dengan hukum tidak ada yang berada diatas hukum. 'No man above the law', artinya tidak ada keistimewaan yang diberikan oleh hukum pada subyek hukum, kalau ada subyek hukum yang memperoleh keistimewaan menempatkan subyek hukum tersebut berada di atas hukum.

Menurut Ramly Hutabarat, makna equality before the law ditemukan di hampir semua konstitusi negara. Inilah norma yang melindungi hak asasi warga negara. Jika dalam konstitusi hal ini dicantumkan, maka konsekuensi logisnya penguasa dan penegak hukum haruslah melaksanakan dan merealisasikan asas ini dalam kehidupan bernegara. Teori equality before the 
law menurut UUD 1945, adalah suatu mata rantai antara hak dan kewajiban yang harus berfungsi menurut kedudukannya masingmasing. Kesamaan di hadapan hukum berarti setiap warga negara harus diperlakukan adil oleh aparat penegak hukum dan pemerintah. Ditinjau dari hukum tata negara, maka setiap instansi pemerintah, terutama aparat penegak hukum, terikat secara konstitusional dengan nilai keadilan yang harus diwujudkan dalam praktik. Namun menegakkan equality before the law bukan tanpa hambatan. Bisa berupa hambatan yuridis dan politis, atau hambatan sosiologis dan psikologis. ${ }^{17}$

Dalam mewujudkan persamaan di hadapan hukum, Indonesia yang telah meratifikasi konsep dan prinsip-prinsip Hak Asasi Manusia yang tertuang di dalam Konstitusi dan semangat Pancasila. Instrumen Hak Asasi Manusia yang telah diratifikasi tercermin didalam UndangUndang No. 39 Tahun 1999 tentang Hak Asasi Manusia, Undang-Undang Nomor 11 Tahun 2005 tentang Konvenan Hak Ekonomi Sosial dan Budaya serta Undang-Undang Nomor 12 Tahun 2005 tentang Konvenan Hak Sipil Politik, dan konvensi-konvensi maupun norma-norma PBB yang lainnya.

Penegasan yuridis tersebut menunjukkan tiga bentuk kewajiban negara (pemerintah) terhadap HAM, yakni: pertama, kewajiban menghormati (to respect), yaitu negara tidak bolehcampurtanganatautidak boleh mengambil tindakan yang mengakibatkan tercegahnya akses terhadap hak yang bersangkutan. Kedua, kewajiban melindungi (to protect), negara harus menjamin bahwa pihak ketiga tidak melanggar hak individu lain dan memberi sanksi kepada mereka yang melanggar. Ketiga, kewajiban memenuhi HAM (to fulfill). Negara harus proaktif dengan mendukung intervensi (positive measures) sehingga hak-hak asasi setiap orang dilindungi, dan proses pemenuhan/perolehan kembali hak-hak asasinya yang belum dapat dipenuhi melalui usaha sendiri, kini proses pemenuhannya dijamin dalam Undang-Undang Nomor 39 Tahun 1999.

Konsep negara hukum ternyata sangatlah erat kaitannya antara negara hukum dengan masalah HAM, sehingga dapat dikatakan bahwa negara hukum adalah sebagai wadah, dan HAM sebagai isi. Pelaksanaan HAM di Indonesia memerlukan koordinasi antar pelbagai unsur, menyadari bahwa persoalan-persoalan HAM di Indonesia masih sangat luas baik hak-hak sipil dan politik, hak-hak ekonomi, sosial dan budaya serta hak untuk berkembang (right to development) dan sebagainya. ${ }^{18}$

Berbicara kedilan sosial, tidak ada pemisahan antara hak sipil politik dengan hak ekonomi sosial dan budaya. Kedua induk HAM ini harus sejalan beriringan. Tidak ada yang diprioritaskan dalam pelaksanaannya. Tentang equality before the law bukan hanya dalam satu sisi diatas. Hak dibidang politik misalnya; hak dasar dibidang politik tercermin dalam Pasal 28 UUD 1945 yaitu "kemerdekaan berserikat dan berkumpul, mengeluarkan pikiran dengan tulisan maupun lisan ditetapkan dalam undang-undang". Selanjutnya Pasal 27 ayat (1), "segala warga negara bersamaan kedudukannya didepan hukum dan pemerintah tidak ada kecualinya". Penjelasan pasal itu

17 Ramly Hutabarat. Persamaan di Hadapan Hukum (Equality Before The Law) di Indonesia (Jakarta: Ghalia Indonesia, 1985), hlm. 59-81.

18 Mien Rukmini, Perlindungan HAM Melalui Asas Praduga Tidak Bersalah dan Asas Persamaan Kedudukan dalam Hukum Pada Sistem Peradilan Pidana Indonesia, (Bandung: Alumni, 2007), hlm. 35-50. 
menegaskan prinsip penting bahwa Indonesia adalah negara hukum dan diperkuat dalam amandemen Pasal 1 Ayat (3) berbunyi "Negara Indonesia adalah negara hukum".

Sebagai negara hukum (rechtsstaat) maka negara harus menjamin persamaan setiap orang di hadapan hukum serta melindungi hak asasi manusia. Persamaan perlakuan di hadapan hukum bagi setiap orang berlaku dengan tidak membeda-bedakan latar belakangnya (ras, agama, keturunan, pendidikan atau tempat lahirnya), untuk memperoleh keadilan melalui lembaga peradilan.

Persamaan di hadapan hukum harus diartikan secara dinamis dan tidak diartikan secara statis. Artinya, kalau ada persamaan di hadapan hukum bagi semua orang maka harus diimbangi juga dengan persamaan perlakuan (equal treatment) bagi semua orang. Persamaan di hadapan hukum yang diartikan secara dinamis ini dipercayai akan memberikan jaminan adanya akses untuk memperoleh keadilan (access to justice) bagi semua orang tanpa memperdulikan latar belakangnya. Menurut Aristoteles, keadilan harus dibagikan oleh negara kepada semua orang, dan hukum yang mempunyai tugas menjaganya agar keadilan sampai kepada semua orang tanpa kecuali. Apakah orang mampu atau fakir miskin, mereka sama untuk memperoleh akses kepada keadilan.

\section{Perlindungan Hukum Terhadap Kelompok Minoritas di Indonesia}

Dari berbagai informasi di media dapat diketahui bahwa sebagian warga negara
Indonesia yang tergolong dalam kelompok minoritas ternyata belum mendapat perhatian yang serius dari pemerintah. Menurut Laporan Tahunan Kebebasan Beragama/Berkeyakinan (KBB) di Indonesia oleh The Wahid Institute tahun 2015, ironisnya negara masih menjadi aktor terbanyak dalam melakukan pelanggaran kebebasan beragama yang pada umumnya terjadi pada kelompok agama minoritas. ${ }^{19}$

Menurut laporan The Wahid Institue tersebut, peristiwa pelanggaran kebebasan beragama/berkeyakinan sepanjang tahun 2015 sebanyak 190 peristiwa dengan 249 tindakan. Jumlah ini naik $20 \%$ dari tahun 2014. Pada 2014 jumlah peristiwa yang dilaporkan sebanyak 158 peristiwa dengan 187 tindakan. Pada 2015, tindakan pelanggaran terbanyak masih dilakukan negara sebanyak 130 tindakan atau 52 \%. Sementara sisanya, 119 tindakan atau $48 \%$ dilakukan aktor non-negara. Hal yang sama terjadi pada 2014, aktor negara juga lebih banyak melakukan tindakan pelanggaran ketimbang non negara. Sebanyak 98 tindakan (52\%) dilakukan negara, sisanya 89 tindakan (48\%) melibatkan non negara.

Grafik 1. Tren Pelanggaran kebebasan beragama dari tahun ke tahun

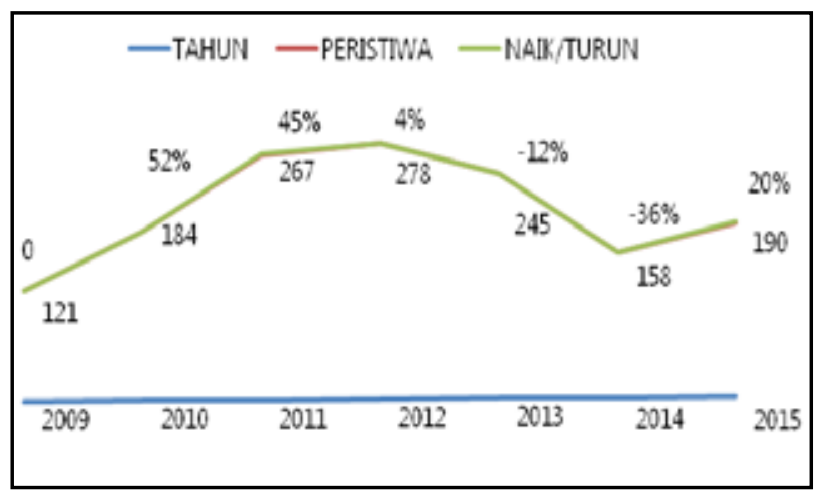

19 The Wahid Institute, Laporan Tahunan Kemerdekaan Beragama/Berkeyakinan (KBB) di Indonesia, (Jakarta, 2015), hlm. 32-40. 
Isu kelompok minoritas seringkali memicu kontroversi berbagai pihak sehingga menghambat upaya penegakan HAM. Menurut Komnas HAM, masyarakat Indonesia secara umum masih awam dalam melihat kelompok minoritas. Sesuatu yang berbeda dengan mainstream atau kebiasaan umum seringkali dianggap asing, abnormal atau kesalahan. Pemahaman itu harus dibenahi karena konstitusi mengamanatkan semua manusia memiliki derajat yang sama sehingga tidak boleh ada diskriminasi atas alasan apapun. Ditegaskan lagi dalam Undang-Undang Nomor 39 Tahun 1999 tentang HAM, termasuk perlakuan dan perlindungan yang sama di depan hukum. Lebih khusus Kovenan Hak-Hak Sipil dan Politik yang telah diratifikasi lewat Undang-Undang Nomor 12 Tahun 2005 menegaskan kepada negara pihak untuk menghormati hak-hak kelompok minoritas meliputi etnis, bahasa atau agama.

Perlindungan untuk minoritas pada situasi global saat ini menjadi makin kompleks. Berbagai program pembangunan yang dicanangkan oleh dunia internasional belum seluruhnya menyentuh pemenuhan hak-hak minoritas. Padahal berbagai pengalaman dan studi telah menunjukkan bahwa kelompok yang paling rentan dan paling miskin pada umumnya berasal dari kelompok minoritas, baik minoritas secara etnis, maupun agama. Hadirnya demokrasi juga tidak serta merta menjamin pemenuhan serta perlindungan hak minoritas. Berbagai pengalaman proses demokrasi di banyak negara menunjukkan bahwa hak-hak minoritas tetap terabaikan meskipun demokrasi telah dipraktekkan (sistem kepartaian, pemilihan langsung, dll). Kepentingan kelompok minoritas tetap tidak terwakili. Lebih lanjut didiskusikan bahwa yang dialami oleh kelompok minoritas adalah marjinalisasi yang masif oleh kelompok mayoritas. Menjadi minoritas berarti tidak memiliki kekuatan, baik sosial, ekonomi dan politik.

Pada dasarnya Indonesia telah dan selalu mengakui hak kelompok minoritas sesuai dengan prinsip dasar Bhinneka Tunggal lka. Hal ini terlihat dalam posisi-posisi di jabatan publik yang dipercayakan kepada beragam suku dan agama di Indonesia. Namun demikian Indonesia juga masih memiliki pekerjaan rumah yang besar untuk perlindungan kelompok minoritas, terutama penegakan hukum. ${ }^{20}$

Gagasan lain yang mengemuka untuk perlindungan kelompok minoritas adalah adanya kebijakan yang bersifat inklusif, kebijakan integrasi kelompok minoritas ke masyarakat mayoritas serta pendidikan bagi anak-anak di sekolah dasar mengenai pluralisme. Tempat yang paling aman bagi kelompok minoritas adalah terintegrasi dengan baik di kelompok mayoritas. Hal lain yang diusulkan adalah menulis ulang sejarah bangsa: apa yang menyebabkan sebuah negara-bangsa bersepakat memiliki sebuah identitas tunggal. Penulisan ulang sejarah akan membuka banyak hal, namun perlu diperhatikan apakah negarabangsa tersebut sudah cukup dewasa dan matang untuk melakukannya. ${ }^{21}$

Hal lain yang penting untuk diperhatikan adalah peranan sosial media dalam perlindungan kelompok minoritas. Kebanyakan orang berpandangan bahwa media sosial memiliki

20 Yogi Zul Fadhli, "Kedudukan Kelompok Minoritas dalam Perspektif HAM dan Perlindungan Hukumnya di Indonesia," Jurnal Konstitusi Volume 11, Nomor 2, Juni (2014).

21 http://ksp.go.id/perlindungan-bagi-kelompok-minoritas/(diakses 2 April 2017). 
dua sisi: melindungi dan sekaligus mencancam. Contoh yang diberikan adalah penggunaan media sosial secara masif dan intensif oleh kelompok radikal. Dalam hal ini dipertanyakan apakah perusahaan media sosial tidak bisa diminta ikut untuk menseleksi informasi yang ditayangkan, untuk meminimalisir dampak negatif. $^{22}$

Melihat keberagaman di Indonesia, Komnas HAM memasukkan beberapa kelompok dalam golongan minoritas seperti penyandang disabilitas, LGBT dan aliran politik minoritas. Komnas HAM mendorong pemerintah untuk memajukan pemenuhan hak-hak kelompok minoritas. Dengan begitu diharapkan ada perlindungan terhadap kelompok minoritas yang menjalankan keyakinannya dan mengekspresikan identitas mereka masingmasing. Selain penuntasan pelanggaran HAM berat masa lalu, pemenuhan dan perlindungan hak-hak kelompok minoritas juga jadi isu prioritas Komnas HAM.

Komnas HAM menekankan pemerintah perlu mengakomodir perlindungan minoritas penyandang disabilitas dan orientasi seksual sesuai instrumen internasional seperti Convention On Rights of Peoples With Disabilities (CRPD) dan Jogjakarta Principle tahun 2006.

Perlindungan terhadap kelompok minoritas di Indonesia sejak reformasi dimulai oleh Presiden B.J Habibie dengan menerbitkan Inpres Nomor 26 Tahun 1998 tentang Menghentikan Penggunaan Istilah Pribumi dan Non Pribumi. Tahun 2000, Presiden Abdurrahman Wahid mengeluarkan Keppres Nomor 6 Tahun 2000 tentang Pencabutan Inpres Nomor 14 Tahun
1967 tentang Agama, Kepercayaan dan Adat Istiadat Cina.

Lewat Undang-Undang Nomor 23 Tahun 2006 tentang Administrasi Kependudukan (UU Adminduk) yang diperbarui oleh UndangUndang Nomor 24 Tahun 2013, secara hukum mencabut ordonansi tentang administrasi berdasarkan atas penggolongan kebangsaan, ras dan agama. Pengakuan atas hak identitas kelompok dan budaya Tionghoa kembali ditegaskan dengan pencabutan SE Presidium Kabinet Ampera Nomor SE-06/Pres.Kab/6/1967 melalui Keppres Nomor 12 Tahun 2014. Undang-Undang Adminduk membuka peluang diskriminasi dan menyulitkan pelayanan perkawinan bagi penganut aliran penghayat, sebab regulasi itu mengatur perkawinan yang sah yaitu disahkan oleh pemuka.

Dalam rangka melindungi ras Papua (Melanesia) pemerintah menerbitkan UndangUndang tentang Otonomi Khusus. Regulasi ini melindungi secara khusus orang asli Papua (OAP). Tapi pelaksanaannya masih diskriminatif, misalnya, di bidang ekonomi, pemerintah memberi ruang yang sangat kecil bagi OAP untuk mengembangkan ekonominya. Begitu pula dengan perbankan, sulit memberi kredit bagi OAP.

Diskriminasi juga dialami kelompok minoritas etnis yang mempertahankan agama leluhur mereka. Komnas HAM menjelaskan Undang-Undang Nomor 23 Tahun 2006 tentang Adminduk dirancang untuk memberikan jaminan kesetaraan setiap warga dalam layanan administrasi kependudukan tanpa memandang latar belakang agama. Jika seorang warga

22 Centre for Innovation and Policy Governance, Media dan Kelompok Rentan di Indonesia: Kisah Dari yang Terpinggirkan, (Jakarta, 2012), hlm. 61-66. 
menganut agama yang belum dicatat oleh negara, kolom agama tidak perlu diisi. Tapi PP No. 37 Tahun 2007 tentang Pelaksanaan Undang-Undang Nomor 23 Tahun 2006 tentang Administrasi Kependudukan mencantumkan bahwa Penghayat Kepercayaan harus memiliki organisasi yang terdaftar pada Kementerian terkait. ${ }^{23}$

Ada sejumlah daerah yang tergolong baik dalam memberikan pelayanan publik termasuk kepada kelompok minoritas. Diantaranya adalah pemerintahan Kabupaten Wonosobo. Pelayanan publik terutama administrasi kependudukan di daerah itu cukup baik dalam menghapus diskriminasi. ${ }^{24}$

Kepedulian terhadap kelompok minoritas di Indonesia juga ditunjukkan oleh berbagai ormas yang cukup berpengaruh. Salah satunya ditunjukkan oleh Muhammadiyah yang pada Muktamar di Makassar tahun 2015 merekomendasikan agar semua orang menghentikan diskriminasi terhadap kelompok ini. Muhammadiyah menganjurkan kepada seluruh institusi yang ada di bawahnya untuk selalu menjadi pelindung terhadap kelompok minoritas yang tertindas. Minoritas yang dimaksudkan dalam rekomendasi itu tidak hanya minoritas agama, tapi mereka yang termarginalkan dan mengalami subordinasi secara sosial seperti buruh, gelandangan dan difabel. ${ }^{25}$

Untuk mewujudkan pemenuhan dan perlindungan HAM kelompok minoritas, Komnas HAM merekomendasikan pemerintah untuk menjadikan kelompok minoritas sebagai penyandang hak dan subyek hukum yang memiliki hak dan kesempatan yang sama sebagaimana warga negara lainnya. Melakukan harmonisasi dan sinkronisasi peraturan perundang-undangan agar sejalan dengan upaya perlindungan dan pemenuhan hak-hak kelompok minoritas.

Berbagai jaminan di atas menunjukkan adanya upaya negara untuk menjalankan kewajiban HAM-nya. Namun demikian, upaya tersebutbelumlahcukupmengingatmasihbelum dinikmatinya hak-hak kelompok minoritas oleh sebagian besarmereka. Salah satu permasalahan dalam penyelenggaraan hak-hak minoritas di Indonesia adalah lemahnya penegakan hukum dan pembangunan yang berkeadilan. Pembangunan ekonomi Indonesia yang masih banyak didasarkan kepada penguasaan modal menjadi salah satu pemicu munculnya berbagai permasalahan sosial minoritas di Indonesia. Adanya ketidakadilan dalam penguasaan sumber daya, dengan pertumbuhan dan kesejahteraan yang tidak berimbang di antara berbagai kelompok identitas masyarakat memicu munculnya konflik horizontal di antara berbagai kelompok masyarakat tersebut. Sikap rasialisme, intoleransi dan berbagai sikap kebencian akan tumbuh subur dalam ketidakadilan pembangunan tersebut. Berbagai permasalahan di atas menunjukkan promosi dan perlindungan hak kelompok minoritas belum terpenuhi secara utuh. Belum terjadinya partisipasi efektif dan bermakna dalam

\footnotetext{
The Wahid Institute \& Tifa Foundation, Policy Brief Layanan Adminduk bagi Kelompok Minoritas, (Jakarta, 2014)

24 http://www.wahidinstitute.org/wi-id/indeks-berita/203-atas-diskriminasi-wi-jalin-kerjasama-denganpemerintah.html

25 Berita Resmi Muhammadiyah Nomor 01, 2015-2020, September 2015, Tanfidz Keputusan Muktamar Muhammadiyah ke-47 Makassar 3-7 Agustus 2015, (Yogyakarta: Pimpinan Pusat Muhammadiyah, 2015), hlm. 127.
} 
proses penyusunan kebijakan pembangunan juga terlihat dari masih banyaknya kebijakan pembangunan yang memicu masalah sosial. ${ }^{26}$

\section{Upaya Pemenuhan HAM Kelompok Minoritas}

Ratifikasi Indonesia atas Deklarasi Universal Hak Asasi Manusia (DUHAM) dan tindakan pemerintah untuk mendukungnya secara eksplisit melalui Undang-Undang Nomor 39 tahun 1999 tentang HAM, belum tampak ketajaman taringnya untuk mengusut secara tuntas pelbagai kasus pelanggaran HAM di Indonesia.

Berkaitan dengan perspektif HAM, keberadaan piagam PBB bisa dimengerti sebagai upaya untuk menegaskan kembali kepercayaan terhadap hak-hak dasar manusia; terhadap martabat dan nilai pribadi manusia; terhadap persamaan hak pria dan wanita dan persamaan negara besar dan kecil. Piagam yang diundangkan pada tahun 1945 itu dimaksudkan untuk mempertahankan perdamaian dan keamanan internasional.

Tujuan DUHAM PBB adalah agar setiap orang dapat mencapai dan memiliki hak-hak asasinya secara adil dan bertanggungjawab (hak hidup, hak atas kebebasan, hak untuk diperlakukan secara adil, hak ekonomi, sosial, budaya, dII). Tujuan mulia itu harus senantiasa diperjuangkan.

Dalam era teknologi informasi yang kian canggih dewasa ini, perspektif HAM meliputi hak setiap orang untuk tidak dilanggar wilayah privasinya, tidak diekspos tentang dirinya kecuali atas izin pribadi yang bersangkutan. Terlepas dari manfaat positif teknologi informasi yang kita alami sekarang ini, ia tetap memiliki implikasi negatif terhadap HAM dalam praksis kehidupan, antara lain wilayah privasi seseorang menjadi kurang aman. Dalam konteks ini, hati nurani dan kesadaran etis terhadap orang lain penting menjadi pertimbangan perspektif kita tentang HAM.

Berkaitan dengan pelanggaran HAM kelompok minoritas, ada enam bentuk tindakan yang merupakan pelanggaran serius terhadap hak-hak asasi mereka dan amat merendahkan kemanusiaannya. Pertama, perlakuan diskriminasi. Kedua, penyiksaan atau intimidasi. Ketiga, eksploitasi. Keempat, perilaku subordinatif. Kelima, pembunuhan dan Keenam, abortus artifisial yang disengaja.

Sekelumit deskripsi perihal bagaimana partisipasi publik (pemerintah dan rakyat pada umumnya) untuk mendukung pemenuhan HAM kelompok rentan atau minoritas: ${ }^{27}$

1) Kelompok Minoritas SARA

Persoalan yang dihadapi oleh mayoritas negara yang penduduknya majemuk dalam agama, etnis, ras adalah diskriminasi. Apapun alasannya, tindakan disriminasi dalam bentuk apapun dan terhadap siapapun adalah pelanggaran terhadap HAM.

2) Kelompok Perempuan Rentan

Rantai pelanggaran terhadap hak asasi kaum perempuan dapat diputus, antara lain dengan cara memberikan hak atas pendidikan dan hak demokrasi. Kedua hak itu menjadi titik berangkat manakala pihak publik hendak memutuskan rantai pelanggaran hak-hak asasi kaum perempuan.

\footnotetext{
26 Komnas HAM, Op. Cit., hlm. 115.

27 Bartolomeus Samho, "Tanggung Jawab dan Partisipasi Publik Dalam Mengatasi Pelanggaran Hak Asasi Kelompok Rentan," Jurnal Hukum Pro Justisia Volume 25 No.1, Januari (2007).
} 
3) Anak-Anak

Berkaitan dengan resiko yang dihadapi anak-anak jalanan dan anak yang tergolong ke dalam kelompok rentan pada umumnya, perlu intervensi publik atas kondisi hidup mereka, misalnya dengan memberikan akses terhadap pelayanan pendidikan, kesehatan dan perlindungan. Dengan demikian, mereka tidak mudah menjadi korban kebijakan politik dan ekonomi yang menguntungkan pihak-pihak "kuat", dan terhindar dari eksploitasi.

4) Tenaga Kerja

Pada umumnya pelanggaran atas hak-hak asasi para tenaga kerja terjadi ketika mereka tidak memiliki posisi tawar yang seimbang dengan pengusaha sebagai pemilik modal dan pemegang tampuk kekuasaan.

5) Manusia Lanjut Usia

Alasan pentingnya tindakan pemeliharaan dan penjagaan hak-hak asasi kelompok lansia tentu berkaitan dengan tanggung jawab etis. Tindakan demikian memberi ruang kepada moralitas.

6) Penyandang Cacat

Salah satu masalah sosial yang dihadapi bangsa Indonesia dewasa ini adalah bagaimana memenuhi hak-hak hidup warga negaranya yang berstatus sebagai penyandang cacat. Mereka yang tergolong penyandang cacat adalah yang mengalami cacat baik fisik maupun mental, sehingga harus memperoleh pelayanan dan perlakuan khusus.

Setiap warga negara berhak mendapat perlindungan HAM oleh negara. Hal ini berarti pemerintah selain mempersiapkan, menyediakan, dan meyusun perangkat hukum HAM, mendirikan kelembagaan HAM, juga harus berupaya memberikan perlindungan HAM kepada seluruh warga negara Indonesia di manapun berada. Seiring upaya pemerintah untuk melindungi warga negara terhadap pelanggaran HAM, masih banyak kita temukan kasus pelanggaran HAM.

Pemerintah sudah melakukan upaya untuk melakukan pemenuhan, penegakan dan perlindungan HAM kelompok minoritas. Itu bisa dilihat dari berbagai regulasi dan kebijakan yang diterbitkan. Misalnya, Kementerian Sosial mendefenisikan kelompok minoritas sebagai bagian dari penyandang masalah kesejahteraan sosial (PMKS) sebagaimana diatur dalam Peraturan Menteri Sosial Nomor 8 Tahun 2012 tentang Peraturan Pedoman Pendataan Dan Pengelolaan Data Penyandang Masalah Kesejahteraan Sosial Dan Potensi Dan Sumber Kesejahteraan Sosial. Kementerian Dalam Negeri menggolongkan kelompok minoritas sebagai bagian dari masyarakat tuna sosial yaitu waria, gay, lesbian dan orang dengan HIV-AIDS. Itu dapat ditemui dalam Peraturan Menteri Dalam Negeri Nomor27 Tahun 2014 tentang Pedoman Penyusunan, Pengendalian dan Evaluasi Kerja Rencana Kerja Pembangunan Daerah tahun 2015. Implementasi kebijakan di tingkat kementerian itu menunjukan kelompok minoritas dalam cakupan ras, etnis, agama, orientasi seksual dan disabilitas menjadi sasaran program pemerintah. Tapi berbagai kebijakan tingkat kementerian itu belum didasarkan pada pemenuhan HAM.

Kita sebagai warga negara harus menghargai upaya pemerintah dalam menegakkan HAM. Bentuk penghargaan itu adalah dengan melibatkan diri dalam upaya pemerintah tersebut. Kita harus berusaha untuk tidak melakukan pelanggaran HAM kepada siapapun serta segera melaporkan kepada pihak yang 
berwenang jika mengetahui adanya pelanggaran HAM.

Peran masyarakat terhadap upaya penegakan HAM, misalnya muncul berbagai aktivis dan advokasi LSM (Lembaga Swadaya Masyarakat). Para aktivis dapat mengontrol atau mengkritisi kebijakan pemerintah yang rawan terhadap pelanggaran HAM. Mereka juga dapat mendata kasus-kasus pelanggaran HAM dan melakukan pembelaan atau pendampingan. Lembaga Swadaya Masyarakat tersebut bisa menangani berbagai masalah, misalnya masalah kesehatan masyarakat, korupsi, demokrasi, pendidikan, kemiskinan, lingkungan, penegakan hukum. Kehadiran mereka dapat menjadi kekuatan penyeimbang sekaligus pengontrol langkahlangkah pemerintah dalam pelaksanaan HAM di Indonesia.

Perdebatan mengenai siapa yang bertanggung jawab dalam menegakkan perjuangan, perlindungan, dan pemenuhan HAM sampai kini menjadi wacana yang tidak berkualitas yang tidak berkesudahan. Dalam kaitan dengan persoalan tersebut terdapat dua pandangan.

Pandangan yang pertama bahwa yang harus bertanggung jawab memajukan HAM adalah negara. Negara dibentuk sebagai wadah untuk kepentingan kesejahteraan rakyatnya. Rakyat perlu diberikan pendidikan, terutama masalah yang berkaitan dengan HAM. Negara yang tidak memfasilitasi rakyat melalui pendidikan HAM, berarti negara tersebut telah mengabaikan amanat rakyat. Negara yang memilki tanggung jawab dalam memberikan jaminan HAM. Oleh karena itu, deklarasi PBB tentang HAM yang dikenal dengan Deklarasi Universal Hak Asasi Manusia, beberapa kovenan, hukum perjanjian internasional, Piagam Madinah, dan Deklarasi Kairo harus diletakkan sebagai norma hukum internasional yang mengatur bagaimana negara-negara di dunia yang menjamin hak-hak individunya.

Setiap warga negara mempunyai hak asasi, baik yang bersifat non derogable rights (hak yang dalam keadaan darurat perang harus dilindungi) maupun derograble rights (hak yang dalam keadaan normal harus dilindungi). ${ }^{28}$ Hak-hak inilah yang harus dijamin realisasinya oleh negara. Apabila negara tidak mampu melindungi HAM warga negaranya, negara yang bersangkutan dengan sendirinya akan kehilangan legitimasi rakyatnya. Dengan demikian, analisis terhadap pelanggaran HAM selalu berada dalam wilayah pelanggaran HAM oleh negara terhadap rakyat. Pelanggaran HAM oleh negaranya terhadap rakyat disebut pelanggaran HAM secara vertikal. Pelanggaran ini tidak hanya berupa pelanggaran HAM secara langsung oleh negara, tetapi juga berupa pelanggaran HAM secara tidak langsung. Pelanggaran tidak langsung terjadi apabila negara membiarkan terjadinya pelanggaran HAM dan tidak melakukan pemenuhan HAM. Undang-Undang Nomor 39 Tahun 1999 tentang HAM berpandangan bahwa tanggung jawab perlindungan, pemajuan, penghormatan, dan pemenuhan HAM ada pada pemerintah

Pandangan kedua menyatakan bahwa tanggung jawab pemajuan, penghormatan, dan perlindungan HAM tidak saja dibebankan kepada negara, melainkan juga kepada warga negara. Dengan demikian, negara dan individu sama-sama memiliki tanggung jawab terhadap pemajuan, penghormatan, dan perlindungan HAM. Oleh karena itu, pelanggaran HAM

28 http://www.hukumonline.com/klinik/detail/lt4d5605606b42e/hak-privasi (diakses 31 Maret 2017). 
sebenarnya tidak saja dilakukan oleh negara kepada rakyatnya, melainkan juga oleh rakyat. Pelanggaran ini disebut sebagai pelanggaran HAM secara horisontal. Contoh bentuk pelanggaran HAM ini antara lain penembakan warga oleh sipil bersenjata, penganiayaan buruh oleh majikan, perampokan, dan ledakan bom bunuh diri ditempat umum oleh para teroris.

Setidaknya ada tiga alasan mengapa warga negara memiliki tanggung jawab dalam penegakan dan perlindungan HAM bagi kelompok minoritas, alasan-alasan tersebut antara lain:

1) Sejumlah besar persoalan HAM tidak hanya melibatkan aspek pemerintah, tetapi juga kalangan swasta atau kalangan di luar negara, dalam hal ini warga negara.

2) Hak asasi manusia bersandar pada pertimbangan-pertimbangan normatif agar umat manusia diperlakukan sesuai dengan martabat kemanusiaannya.

3) Warga negara memiliki tanggung jawab atas dasar prinsip-prinsip demokrasi. Setiap warga negara memiliki kewajiban untuk ikut mengawasi tindakan pemerintah. Dalam masyarakat yang demokratis, sesuatu yang menjadi kewajiban pemerintah juga menjadi kewajiban warga negara.

Kendala yang terjadi dalam upaya pemenuhan HAM kelompok minoritas ditandai dengan banyaknya kasus pelanggaran HAM. Hal ini menunjukkan masih lemahnya sistem penegakan hukum dan lemahnya political will pemerintah dalam mengimplikasikan normanorma HAM. Kekuasan yang dimiliki oleh negara justru sering dimanfaatkan oleh pemerintah sebagai alat untuk mempertahankan kekuasaan. Rendahnya tingkat kesadaran hukum dari warga masyarakat juga menjadi sebab terjadinya pelanggaran HAM.

Penegakan HAM mempunyai relevansi dengan masyarakat madani karena nilai-nilai persamaan, kebebasan, dan keadilan yang terkandung dalam HAM dapat mendorong terciptanya masyarakat egaliter. Masyarakat egaliter merupakan ciri masyarakat madani. Dengan demikian, penegakan HAM merupakan prasyaratuntukmenciptakan sebuah masyarakat madani. Dalam upaya mewujudkan masyarakat madani yang terpenting adalah masyarakat harus berada dalam posisi mandiri di hadapan kekuasaan negara. Di tengah masyarakat tersebut harus pula ditegakkan keadilan dan supremasi hukum sehingga terwujud kehidupan yang demokratis dan toleran.

Pengakuan adanya hak asasi pada seseorang berarti mengakui pula adanya kewajiban asasi semua orang untuk menghormati hak asasi yang dimiliki oleh orang lain. Batas HAM yang satu adalah hak asasi orang lain. Dengan demikian, hubungan antara hak dan kewajiban adalah resiprokal yang harmonis karena pengakuan hak pada pihak tertentu berimplikasi kewajiban pada pihak lain.

\section{Penutup}

Pemerintah saat ini sudah melakukan upaya untuk melakukan pemenuhan, penegakan dan perlindungan HAM kelompok minoritas. Itu bisa dilihat dari berbagai regulasi dan kebijakan yang diterbitkan. Perlindungan hukum terhadap hak asasi kelompok minoritas di Indonesia diatur, dalam kerangka prinsip kesetaraan di hadapan hukum dan non diskriminasi, diatur dalam Pasal 28 D dan Pasal 28 I UUD 1945, serta tercantum juga di Pasal 3 Ayat (3) Undang-Undang Nomor 39 Tahun 1999 tentang HAM. Sedangkan Pasal 27 
Kovenan Internasional Hak-Hak Sipil dan Politik (International Covenant and Political Rights) yang telah diratifikasi dengan Undang-Undang Nomor 12 Tahun 2005 tentang Pengesahan ICCPR 1966 mengatur bahwa kelompok minoritas tersebut tidak dapat diingkari haknya. Sedangkan di Undang-Undang Nomor 39 Tahun 1999 tidak terang menyinggung perlindungan terhadap kelompok minoritas.

Pemerintah wajib memastikan perlindungan terhadap kaum minoritas. Menjalankan hukum yang menentang diskriminasi dalam segala bidang. Dalam rekrutmen, fasilitas perumahan, kesehatan, akses ke pendidikan sampai ke dalam aturan hukum dan peraturan perundangundangan.

Namun, mengandalkan aturan hukum saja tidak cukup. Kita perlu lebih mengedepankan hati dan empati. Hal ini mengingatkan pada ucapan sebuah karakter besar dalam fiksi Amerika, Atticus Finch, yang mengatakan bahwa, "You never really understand a person until you consider things from his point of view ... until you climb into his skin and walk around in it." Kamu tidak akan benar-benar memahami seseorang, sampai kamu mempertimbangkan hal-hal dari sudut pandang orang tersebut, sampai kamu memanjat kulitnya dan berjalanjalan di sekitar itu."

Manakala kita hidup dalam masyarakat yang majemuk dalam segala hal, advis itu perlu juga kita pertimbangkan. Sulit bagi kita berempati dan menghormati warga agama minoritas, jika kita seumur hidup tinggal di tengah warga mayoritas.

Seperti dikatakan oleh berbagai pihak bahwa produk hukum ada, tetapi tidak cukup. Butuh empati. Kesadaran solidaritas yang mendasar.

Sudah sepatutnya pemerintah mengedepankan pendekatan berbasis HAM (rights based approach) dalam seluruh proses pembangunan program dan kebijakan yang disusun sesuai dengan upaya perlindungan dan pemenuhan hak-hak kelompok minoritas dan marjinal. Menjadikan kelompok minoritas sebagai penyandang hak dan subjek hukum yang memiliki hak dan kesempatan yang sama sebagaimana warga negara lainnya serta melakukan harmonisasi dan sinkronisasi peraturan perundang-undangan sejalan dengan upaya perlindungan dan pemenuhan hak-hak kelompok minoritas.

Implementasi HAM terhadap kelompok minoritas di Indonesia harus berdasarkan falsafah Pancasila. Karena itu, segala hukum yang berlaku dalam mewujudkan ketertiban untuk kesejahteraan masyarakat, semuanya harus berlandaskan HAM yang bermula dan digali dari Pancasila dengan mengutamakan hak dan kewajiban guna mendatangkan keadilan untuk kedamaian (justice for peace) bagi seluruh masyarakat.

\section{Daftar Pustaka}

\section{Buku}

Atmasasmita, Romli, Teori Hukum Integratif. Rekonstruksi Terhadap Teori Hukum Pembangunan dan Teori Hukum Progresif, (Yogyakarta: Genta Publishing, 2012)

Caraj, Marie dan Enrique Eguren, Manual Perlindungan Terbaru Bagi Pembela Hak Asasi Manusia, (Brussels: Protection International, 2008)

Fuady, Munir, Teori-Teori Besar (Grand Theory) Dalam Hukum, (Jakarta: Kencana, 2013)

Hutabarat, Ramly, Persamaan di Hadapan Hukum (Equality Before The Law) di Indonesia (Jakarta: Ghalia Indonesia, 1985)

Rahardjo, Satjipto, Hukum dan Perubahan Sosial. Suatu Tinjauan Teoretis serta PengalamanPengalaman di Indonesia, (Bandung: Alumni, 1983)

Rukmini, Mien, Perlindungan HAM Melalui Asas Praduga Tidak Bersalah dan Asas Persamaan 
Kedudukan dalam Hukum Pada Sistem Peradilan Pidana Indonesia, (Bandung: Alumni, 2007)

Siregar, Bismar, Kata Hatiku, Tentangmu Bismar Siregar: Refleksi 80 Tahun Perjalanan Hidup Seorang Hamba Allah, (Jakarta: Diandra Press, 2008)

Soekanto, Soerjono dan Sri Mamudji, Penelitian Hukum Normatif. Suatu Tinjauan Singkat, (Jakarta: Raja Grafindo Persada, 2004)

\section{Makalah/Artikel/Laporan/Hasil Penelitian}

Bartolomeus Samho, "Tanggung Jawab dan Partisipasi Publik Dalam Mengatasi Pelanggaran Hak Asasi Kelompok Rentan," Jurnal Hukum Pro Justisia, Januari 2007, Volume 25 No.1

Berita Resmi Muhammadiyah Nomor 01, 20152020, September 2015, Tanfidz Keputusan Muktamar Muhammadiyah ke-47 Makassar 3-7 Agustus 2015, (Yogyakarta: Pimpinan Pusat Muhammadiyah, 2015)
Centre for Innovation and Policy Governance, Media dan Kelompok Rentan di Indonesia: Kisah Dari yang Terpinggirkan, (Jakarta, 2012)

Komnas HAM, Upaya Negara Menjamin HakHak Kelompok Minoritas di Indonesia. Sebuah Laporan Awal, (Jakarta, 2016)

The Wahid Institute \& Tifa Foundation, Policy Brief Layanan Adminduk bagi Kelompok Minoritas, (Jakarta, 2014)

The Wahid Institute, Laporan Tahunan Kemerdekaan Beragama/Berkeyakinan (KBB) di Indonesia, (Jakarta, 2015)

Yogi Zul Fadhli, "Kedudukan Kelompok Minoritas dalam Perspektif HAM dan Perlindungan Hukumnya di Indonesia," Jurnal Konstitusi Volume 11, Nomor 2, Juni (2014) 